\title{
DISTRIBUSI KARANG DAN IKAN KARANG DI KAWASAN REEF BALL TELUK BUYAT KABUPATEN MINAHASA TENGGARA
}

\author{
(Distribution of Coral Reefs and Fish in Buyat Bay Area Reef Ball Southeast Minahasa \\ Regency)
}

\author{
Indri Manembu ${ }^{1}$, Luky Adrianto ${ }^{2}$, Dietriech G. Bengen ${ }^{2}$, Ferdinan Yulianda $^{2}$ \\ ${ }^{1}$ Mahasiswa Program Doktor SPs Institut Pertanian Bogor, Bogor. \\ ${ }^{1}$ Fakultas Perikanan dan Ilmu Kelautan Institut Pertanian Bogor, Bogor
}

\begin{abstract}
The placement of reef ball in Buyat Bay and surrounding areas have been carried out since 1999 by PT. Newmont Minahasa Raya. The goal of this placement was to build a habitat for many biota associated with reef thus may improve economically important fish populations. The presence of reef fish on the reef ball is ecologically and economically indispensable. Furthermore, the degradation of reefs might cause the disappearance of economic value of goods and services, as mell as the disappearance of food security and employment for coastal communities, who generally live in poverty. Overall, percent cover of live coral was found at a depth of $3 \mathrm{~m}$ is $56.70 \%$ and $10 \mathrm{~m} / \mathrm{s} 30.4 \%$. The composition of fish species found consists of 19 families, 34 genera, 50 species and 290 individuals most dominant were species of the family Mullidae. As time went by and the increase of reef ball age, some species seem have settled permanenly such as Lutjanus kasmira and several species of the Acanthuridae family. In addition, the presence of reef ball helps the formation of a hew coral reef ecosystem and increase the fertility of waters, therefore enhancing the presence of reef fish community, which might increases the income of fishermen.
\end{abstract}

Keywords: reef ball, coral reef, reef fish.

Penempatan reef ball di perairan Teluk Buyatdan sekitarnya telah dilakukan pada tahun 1999 oleh PT. Newmont Minahasa Raya. Tujuan penempatan reef ball untuk membangun habitat berbagai biota yang berasosiasi dengan karang sehing ga dapat meningkatkan populasi ikan ekonomis penting. Kehadiran ikan karang pada reef ball sangat penting secara ekologis dan ekonomis. Penurunan kualitas terumbu berarti hilangnya nilai ekonomi barang dan jasa, serta hilangnya jaminan makanan dan pekerjaan untuk masyarakat pesisir, yan̆g umumnya hidup dalam kemiskinan. Secara keseluruan, presentasi tutupan karang hidup yang ditemukan pada kedalaman $3 \mathrm{~m}$ adalah $56,70 \%$ sedangkan pada kedalaman $10 \mathrm{~m}$ adalah 30,40\%. Komposisi spesies ikan yang ditemukan terdiri dari 19 famili, 34 genus, 50 spesies dan 290 indiddu,yang tertinggi dihuni oleh jenis dari famili Mullidae. Seiring dengan bertambahnya waktu dan usia reef ball, beberapa spesies terlihat sudah menetap seperti Lutjanus kasmira dan beberapa spesies dari famlli Acanthuridae. Keberadaan reef ball membantu terbentuknya ekosistem terumbu karang yang bary dan meningkatkan kesuburan perairan, sehingga lebih meningkatkan keberadaan komunitas, ikan karang, yang pada akhirnya meningkatkan pendapatan nelayan dari hasil tangkapan ikan karang.

Kata kunci: Reef ball, karang batu, ikan karang.

(1)

\section{PENDAHULUAN}

Terumbu karang merupakan salah satu ekosistem pesisir yang paling produktif dan memiliki biodiversitas tinggi karena keragamannya. Peningkatan intensitas pemanfaatan ekosistem terumbu karang mengakibatkan tekanan terhadap ekosistem semakin berat. Isu utama saat ini sebagai salah satu penyebab degradasi terumbu karang adalah pemutihan karang di Timur Karibia disebabkan oleh kenaikan suhu yang berhubungan dengan kegiatan antropogenik (Donner et al. 2007), serta kejadian pemu- tihan karang, penyakit dan kematian karang di US Virgin Islands (Manzello et al. 2007; Miller et al. 2006). Degradasi ekosistem terumbu karang akibat pemanasan global terus terjadi dari waktu ke waktu, sehingga rehabilitasi terumbu karang merupakan suatu kebutuhan yang mendesak. Penelitian di sekitar Teluk Buyat oleh Rembet et al. (2011b) mendapatkan bahwa status keberhasilan pengelolaan berkelanjutan di kawasan terumbu karang P. Hogow dan P. Putus-Putus perlu memperhatikan persentase penutupan karang (dimensi ekologi); waktu yang digunakan untuk pemanfaatan terumbu 
karang dan ketergantungan kepada sumberdaya sebagai sumber nafkah (dimensi ekonomi); tingkat pendidikan dan upaya perbaikan kerusakan ekosistem terumbu karang (dimensi sosial); tradisi/budaya dan koperasi (dimensi kelembagaan); serta teknologi perahu dan pasca panen (dimensi teknologi).

Reef ball merupakan salah satu bahan alternatif yang dapat digunakan untuk rehabilitasi terumbu karang (Bachtiar dan Prayogo, 2008). Menurut Maher (2004), rehabilitasi terumbu karang merupakan upaya untuk mengembalikan komunitas karang batu tanpa melihat jenis karang yang akan tumbuh di habitat tersebut karena mengandalkan rekruitmen dari larva karang secara alami.

Salah satu fungsi ekologis terumbu buatan adalah menciptakan habitat baru. Terumbu buatan dapat meningkatkan kelimpahan ikan karena ketersediaan shelter (tempat berlindung), di mana sumber bahan makanan yang ada di terumbu kurang penting bagi ikan yang menempatinya (Miller dan Falace, 2000). Fungsi lainnya adalah meningkatkan biomassa ikan. Terumbu buatan dapat meningkatkan populasi ikan diduga melalui dua mekamisme: a) Jika shelter membatasi populasi ikan maka tambahan shelter yang diberikan oleh terumbu buatan akan dapat mengumpulkan sumberdaya ikan lebih banyak dari daerah pantai; b) Jike makanan membatasi populasi ikan, 'maka produksi primer baru dan produksi sekunder organisme benthik didukung oleh terumbu buatan akan menyokong rantai makanan baru yang pada akhirnya akan meningkatkan biomassa ikan (Bohnsack et al 1991). Fungsi lainnya lagi adalah memperbaiki kualitas perairan. Organisme faut yang filter-feeder atau suspention-feeding mempunyai potensi yang baik untuk memperbaiki kualitas perairan di daerah eutrofikasi tinggi dan konsentrasi partikel terlarut yang padat (Seaman dan Jensen 2000). Penelitian ini bertujuan menganalisis hubungan karakteristik biofisik perairan dengan peranan ekologis reef ball, serta mengetahui keefektifannya dalam pembentukan ekologis terumbu karang alami.

\section{METODE PENELITIAN}

Lokasi penelitian dilakukan di Teluk Buyat yang terletak di pantai selatan Sulawesi Utara. Lokasi ini secara administratif berada di Kecamatan Ratatotok, Kabupaten Minahasa
Tenggara. Pengambilan data dilakukan pada bulan Maret 2012.

Variabel data yang diamati ialah parameter kualitas perairan dan monitoring kondisi terumbu karang. Pengambilan data potensi ekosistemnya dilakukan dengan teknik LIT atau Line Intercept Transect (UNEP 1993) dengan panjang transek $50 \mathrm{~m}$. Pengambilan data ikan karang menggunakan metode Sensus Visual (Dartnall dan Jones 1986).

\section{Analisa Kualitas Air}

Pengukuran sampel kualitas air-cílakukan untuk mengetahui karakteristk biofisik perairan yang meliputi kondisi fisika, kimia dan biologi perairan. Pengukuran dan analisis parameter kimia dan biologi dilakukan di laboratorium dan beberapa parameter secara in situ.

\section{Analisa Potensi Terumbu Karang}

Analisis keanekaragaman jenis (genus) karang batu dan likan karang dilakukan dengan menggunakan formulasi Shannon-Wiener:

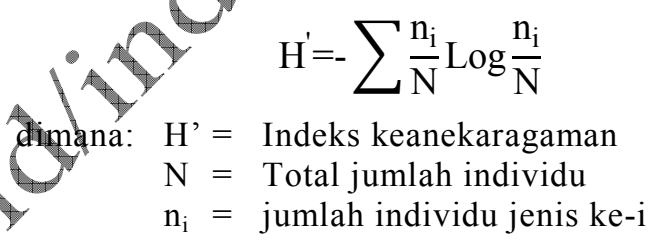

Selain itu dilakukan juga perhitungan nilai kerapatan, kerapatan relatif, dominasi, dominasi relatif, frekuensi relatif dan nilai penting.

Analisis persentase total tutupan karang dilakukan dengan menggunakan formulasi Gomez dan Yap (1978):

$$
\begin{aligned}
& \operatorname{Pc}(\%)=\frac{\mathrm{Tpt}}{\mathrm{pt}} \times 100 \\
& \text { dimana: } \mathrm{Pc}= \text { Percent cover }(\%) \\
& \mathrm{Tpt}= \text { Total panjang transek yang ditutupi } \\
& \text { oleh karang (meter) }
\end{aligned}
$$

\section{HASIL DAN PEMBAHASAN}

\section{Kondisi Fisik Kimia Lokasi Penelitian}

Suhu rata-rata perairan Teluk Buyat pada bagian permukaan relatif stabil, berkisar antara $30,5-31^{\circ} \mathrm{C}$. Salinitas perairan bervariasi menurut musim. Tomascik et al. (1997) menyatakan bahwa salinitas permukaan berkisar antara 31,5-34,5\%. Salinitas permukaan yang terukur berkisar antara 32-33\%o. Nilai salinitas yang cukup tinggi ini bisa disebabkan oleh 
pengaruh salinitas dari massa air Laut Maluku yang masuk.

Kecepatan arus terukur relatif rendah. Hal ini lebih disebabkan lokasi pengukuran terletak di atas rataan terumbu karang (reefflat) yang kedalaman airnya hanya berkisar 1-3 meter. Nilai $\mathrm{pH}$ yang diperoleh berkisar antara 7 8 merupakan nilai yang umum ditemukan pada perairan pantai khususnya di daerah terumbu karang. Seluruh nilai yang diperoleh, masuk pada kisaran nilai yang baik.

Kandungan nitrat $(5,05-5,43)$, nitrit $(0,014-0,027)$, dan fosfat $(0,03-0,19)$ masuk pada kisaran nilai yang baik untuk kegiatan budidaya. Wilayah Teluk Buyat memiliki pantai berpasir dan ke arah luar teluk, merupakan rataan terumbu karang. Kondisi pantainya cocok untuk dikembangkan sebagai kawasan wisata pantai.

\section{Distribusi Karang Batu}

Persentase tutupan karang hidup yang diperoleh pada kedalaman $3 \mathrm{~m}$ adalah $56,70 \%$. Berdasarkan kriteria Yap dan Gomes (1984), terumbu karang pada kedalaman $3 \mathrm{~m}$ dalam kondisi baik. Indeks keragaman (H') di kedalaman $3 \mathrm{~m}$ ini adalah 0,88. Menurut Stodart dan Johnson dalam Sutarna (1991), nilai ini tergolong produktif.

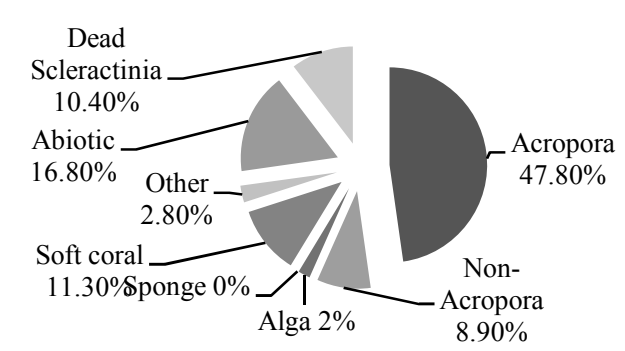

Gambar 1. Persentase tytupan komponen penyusun terumbakarang Teluk Buyat $3 \mathrm{~m}$.

Kondisi terumbu karang dengan kategori terbaik ditemukan pada Acropora dengan panjang Koloni 23,90 m, 14 koloni dan persentase tutupan $47,80 \%$. Kondisi terumbu karang yang baik perlu dijaga, mengingat adanya bekas-bekas penggunaan metode penangkapan ikan yang merusak terumbu karang seperti penggunaan bius dan bom yang pernah dilakukan pada waktu lalu di lokasi ini. Bekas tersebut dapat dilihat dari banyaknya rubble (patahan karang) akibat penggunaan bom, serta banyaknya karang bleaching (pemutihan karang) yang kemungkinan akibat penggunaan zat bius dalam penangkapan ikan.
Persentase tutupan karang hidup yang diperoleh pada kedalaman $10 \mathrm{~m}$ adalah $30,40 \%$. Berdasarkan kriteria kategori Yap dan Gomes (1984), terumbu karang pada kedalaman $10 \mathrm{~m}$ dengan persentase tutupan karang batu $30,40 \%$ dikategorikan dalam kondisi cukup baik. Indeks keragaman (H') di kedalaman ini 1,22. Berdasarkan kategori dari Stodart dan Johnson dalam Sutarna (1991), maka terumbu karang pada kedalaman ini tergolong sangat produktif.

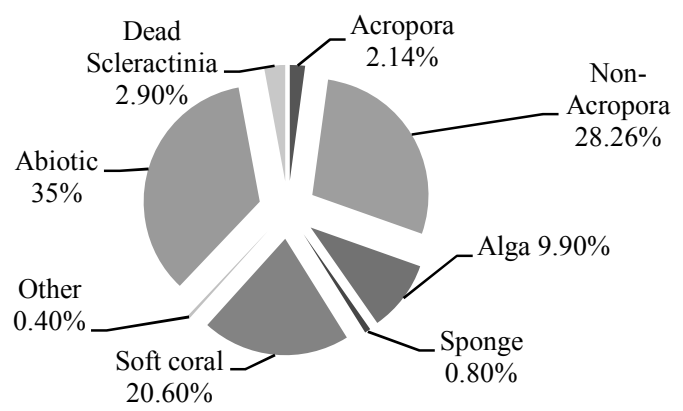

Gambar 2. Persentase Tútupan komponen penyusun terunbu karang Teluk Buyat $10 \mathrm{~m}$.

Persentdse tutupan komponen biotik $62,1 \%$ menunjukkan kondisi ekosistem terumbu karang dalam kondisi yang baik. Walaupun detpíkian tutupan pasir dan rubble yang tinggi di beberapa tempat megindikasikan perlu adanya usaha pengelolaan yang lebih intensif, guna menjaga kelestarian ekosistem terumbu karang yang ada.

\section{Distribusi Ikan Karang}

Komunitas ikan karang mempunyai hubungan yang erat dengan terumbu karang sebagai habitatnya. Struktur fisik dari karang batu Scleractinia sangat cocok berfungsi sebagai habitat dan tempat berlindung bagi ikan karang, di mana: (1) Beberapa jenis ikan karang menggunakan habitat ini sebagai tempat berlindung dari predator dan merupakan daerah yang aman untuk tumbuh dewasa; (2) Daerah ini merupakan tempat mencari makan di mana sejumlah ikan karang memanfaatkan karang secara langsung (Rembet et al. 2011a). Selanjutnya dinyatakan bahwa sekitar $50-70 \%$ ikan yang ada di terumbu karang merupakan kelompok ikan karnivor, 15-20\% kelompok herbivor dan sisanya omnivor. Ikan dari kelompok tersebut sangat bergantung kepada kesehatan karang untuk mengembangkan populasinya.

Spesies Indikator. Hasil pengambilan data kondisi ikan karang di lokasi pengamatan Teluk Buyat, khususnya kelompok spesies indikator (Famili Chaetodontidae), terdiri dari 59 individu dari 12 spesies dan 4 genus. Hasil 
pengamatan berdasarkan jumlah spesies dan individu per kedalaman, mendapatkan bahwa kondisi spesies indikator yang tertinggi ditemukan pada kedalaman 3 m yaitu 9 spesies dan 40 individu, sedangkan pada kedalaman $10 \mathrm{~m}$ diperoleh 7 spesies dan 19 individu.

Dilihat dari komposisi spesies, spesies indikator yang ditemukan didominasi oleh spesies Chaetodon kleinii. Keadaan ini menunjukkan bahwa spesies tersebut memiliki relung ekologi yang luas dan tidak terpengaruh dengan perubahan-perubahan komposisi habitat atau kondisi terumbu karang.

Spesies Target. Kelompok spesies target yang ditemukan pada pengamatan terdiri dari 856 individu dari 45 spesies, 20 genera dan 11 famili. Berdasarkan komposisi, distribusi dan kelimpahan spesies, ditemukan beberapa spesies dari famili tertentu, merupakan spesies yang dominan, yaitu Acanthuridae (8 spesies) dan Scaridae (7 spesies). Selain itu terlihat bahwa kedalaman $3 \mathrm{~m}$ memiliki jumlah indivi$\mathrm{du}$ dan spesies yang lebih tinggi dibandingkan dengan kedalaman $10 \mathrm{~m}$.

Kondisi yang diperoleh pada ikan karang (baik spesies indikator maupun spesies target) mengikuti kondisi yang diperoleh pada karang batu. Secara umum, kondisi terumbu karang (persentase tutupan, keanekaragaman, maupun jumlah koloni karang batu) di Teluk Buyat menunjukkan kondisi yang lebih(baik pada kedalaman $3 \mathrm{~m}$.

\section{Komunitas Ikan di Reef Ball}

Secara keseluruan, komposisi spesies yang ditemukan terdiri dari $\$ 9$ famili, 34 genus, 50 spesies dan 290 indixidur. Kondisi yang ditunjukkan di atas, menginformasikan bahwa komunitas ikan karang yäng menghuni reef ball tertinggi dihuni, oteh jenis dari famili Mullidae. Hal ini dapat ferjadi dan dipahami karena tingkat hunian 1kar karang di habitat baru (buatan) lebih banyak dipengaruhi oleh letak reef ball. Padå Teluk Buyat, reef ball diletakkan berjauhar dengan terumbu karang alami sehingga jenis-jenis ikan yang ada berbeda komposisinya dengan yang ada di terumbu karang alami. Beberapa spesies yang ditemukan dominan adalah kelompok spesies dari famili Acanthuridae (Zebrasoma scopas), Mullidae (Parupeneus multifasiatus), dan Pomacentridae. Seiring dengan bertambahnya waktu dan usia reef ball, beberapa spesies terlihat sudah menetap seperti
Lutjanus kasmira dan beberapa spesies dari famili Acanthuridae.

\section{KESIMPULAN}

Kondisi terumbu karang Teluk Buyat dalam kondisi baik dan mempelihatkan kehadiran beberapa spesies ikan yang memiliki preferensi habitat yang luas dengan kelimpahan yang tinggi, seperti Zanclus cornutus dan Zebrasoma scopas. Keberadaan reef balt telah membantu terbentuknya ekosistem/terumbu karang yang baru dan meningkatkan kestuburan perairan, sehingga lebih meningkatkan keberadaan komunitas ikan karang, yang pada akhirnya meningkatkan pendapatan nelayan dari hasil tangkapan ikan karang.

\section{DAFTAR PUUSTAKA}

Bachtiar I, Prayogd Wo 2008. Rekruitmen karang batu pada reef ball setelah 3 tahun di Teluk Benete Kabupaten Sumbaula Barat. Prosiding Munas Terumbu Karang 1, 10-11 September 2007. Jakarta. 77-85 pp.

Bohnsack JA. 1991. Are high densities of fishes at artificial reefs the result of habitat limitation or behaviour preference Bull. Mar. Sci. 44: 631-645.

Dartnall AJ, Jones M. 1986. A Manual of Survey Methods; Living Resources in Coastal Areas. ASEAN-Australia Cooperative Program On Marine Science Handbook. Townsville: Australian Institute of Marine Science. $166 \mathrm{p}$.

Donner S, Knutson T, Oppenheimer M. 2007. Modelbased assessment of the role of human-induced climate change in the 2005 Carribean coral bleaching event. Proceedings of the National academy of science 104 (13): 5483-5488

Maher T. 2004. Coral rescue and propagation on a submerged artificial reef breakwater in Antigua, West Indies. Proceedings of the 2004 Florida Artificial Reef Summit, April 27-28. 46 p.

Manzello DP, Brandt M, Smith TB, Lirman D, Hendee JC, Nemeth RS. 2007. Hurricanes benefit bleaches corals. Proceedings of the National academy of science 104 (29): 12035-12039.

Miller J, Waara R, Muller E, Rogers C. 2006. Coral bleaching and disease combine to cause extensive mortality on reefs in US Virgin Islands. Coral Reefs 25(3):418.

Miller MW, Falace A. 2000. Evaluation method for trophic resource nutrients, primary production and associated assemblages (95-126). In Seaman, W.Jr. Artificial reef evaluation, with application to natural marine habitats. CRC Press. New York.

Rembet UNWJ, Boer W, Bengen DG, Fahrudin A. 2011 a. Struktur komunitas ikan target di terumbu karang Pulau Hogow dan Putus-putus Sulawesi Utara. J. Perikanan dan Kelautan Tropis VII (2): 60-65.

Seaman W Jr., Jensen AC. 2000. Purposes and practices of artificial reef evaluation (1-19). In Seaman, W.Jr. 
Artificial reef evaluation with Application to natural marine habitats. CRC Press. New York.

Sutarna IN. 1991. Kondisi dan Produktivitas Karang Batu di Tanjung Selatan, Pulau Ambon. Perairan Maluku dan Sekitarnya. BPPSL-P3O-LIPI Ambon. 23-29 pp

Tomascik T. 1997. Coral Reef Ecosystems Environmental Management Guidelines. KLH/EMDI. Jakarta. 164 p
UNEP [United Nation Environmental Program], 1993. Monitoring Coral Reefs For Global Change. Regional Seas. Reference Methods For Marine Pollution Studies No. 61. Australian Institute of Marine Science. $60 \mathrm{p}$.

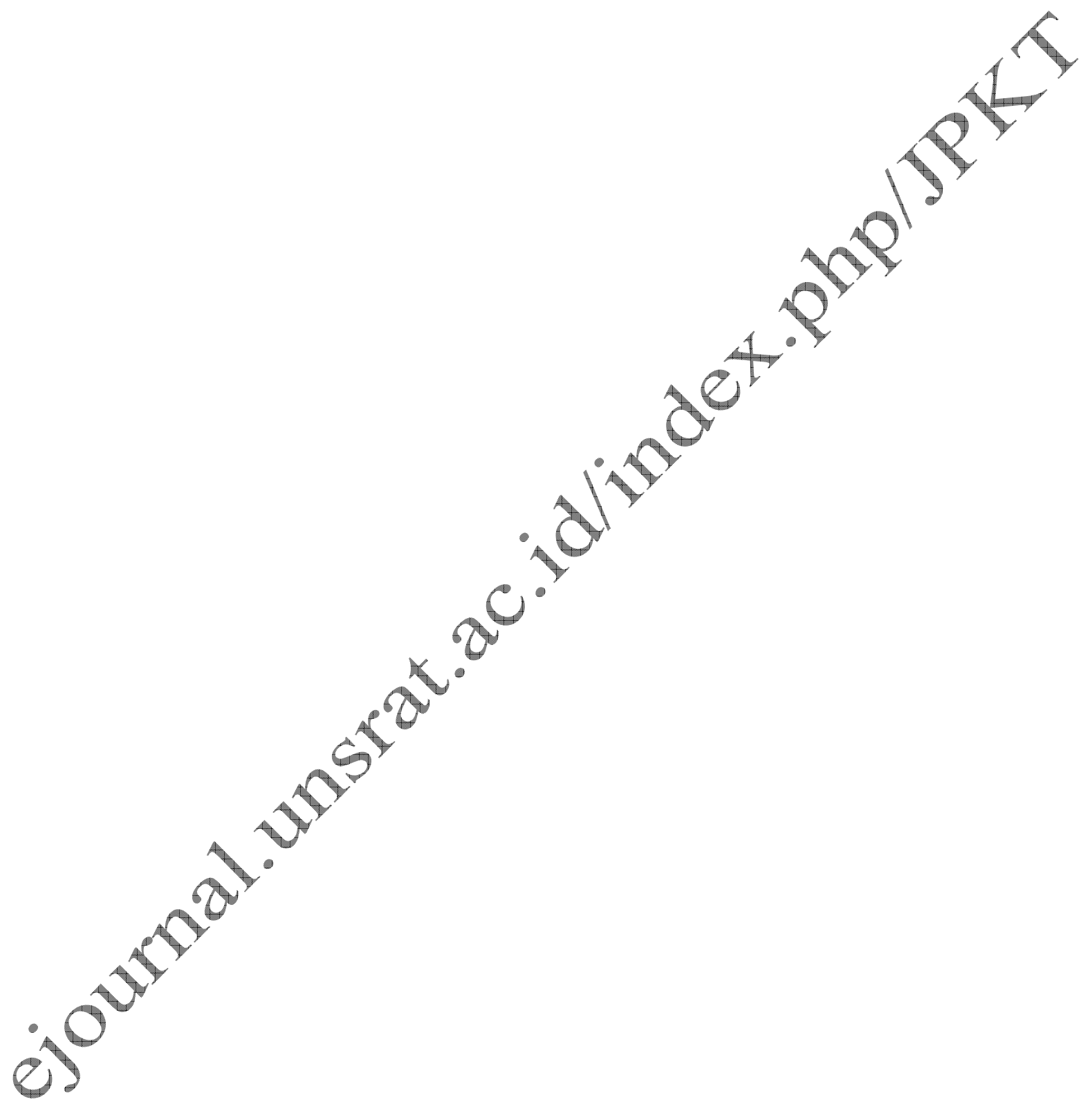

